\title{
Effect of organic matrices on the determination of the trace element chemistry (Mg, Sr, Mg/Ca, Sr/Ca) of aragonitic bivalve shells (Arctica islandica) - Comparison of ICP-OES and LA-ICP-MS data
}

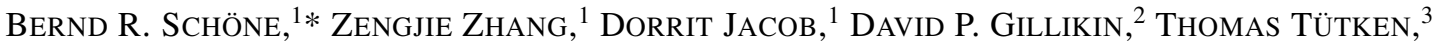 \\ Dieter GARbe-SchÖNBERG, ${ }^{4}$ Ted MCCONNAUGHEY ${ }^{5}$ and AnAlía SOldati ${ }^{1}$ \\ ${ }^{1}$ Institute of Geosciences and Earth System Science Research Center, University of Mainz, \\ Johann-Joachim-Becherweg 21, 55128 Mainz, Germany \\ ${ }^{2}$ Department of Earth Science and Geography, Vassar College, Poughkeepsie, NY 12604, U.S.A. \\ ${ }^{3}$ Steinmann Institute of Geology, Mineralogy and Palaeontology, University of Bonn, \\ Poppelsdorf Castle, 53115 Bonn, Germany \\ ${ }^{4}$ Institute of Geosciences, University of Kiel, Ludewig-Meyn-Straße 10, 24118 Kiel, Germany \\ 52906 Norman Dr., Boise, ID 83704, U.S.A.
}

(Received September 1, 2008; Accepted May 31, 2009)

\begin{abstract}
The element chemistry of biogenic carbonates can provide important data on past environments. However, the $\mathrm{Sr} / \mathrm{Ca}$ and $\mathrm{Mg} / \mathrm{Ca}$ ratios as well as the $\mathrm{Mg}$ and $\mathrm{Sr}$ concentrations of biological carbonates, especially aragonitic bivalves often depart from apparent thermodynamic equilibrium. When measured in situ by means of LA-ICP-MS, the Mg concentration is often substantially enriched (two- to threefold) near the organic-rich, annual growth lines. To test the hypothesis that some organic components exert a major influence on the skeletal metal content, the element chemistry of different shell components (insoluble organic matrix, IOM; dissolved $\mathrm{CaCO}_{3}$ and soluble organics, $\mathrm{SOM}$ ) of Arctica islandica was measured by means of ICP-OES and LA-ICP-MS. The ICP-OES data indicate that the IOM is strongly enriched in Mg (130 $\mathrm{ppm})$ and depleted in $\mathrm{Sr}$ and $\mathrm{Ca}(10 \mathrm{ppm}$ and $0.22 \mathrm{wt} \%$, respectively) when compared to the whole biomineral (Mg: 68 to $99 \mathrm{ppm}, \mathrm{Sr}: 860$ to $1,060 \mathrm{ppm}, \mathrm{Ca}: \sim 35.72 \mathrm{wt} \%)$. Although the average relative abundance of the IOM barely exceeds 0.46 $\mathrm{wt} \%$, its chemical composition in combination with its heterogeneous distribution across the shell can significantly increase estimates of the Mg concentration if measured in situ by LA-ICP-MS. Depending on the distribution of the IOM, the Ca concentration may be significantly lower locally than the average Ca concentration of the whole shell (35.72 wt $\%)$. If this remains undetected, the $\mathrm{Mg}$ concentration of shell portions with higher than average IOM content is overestimated by LA-ICP-MS and, conversely, the Mg concentration is underestimated in shell portions with lower than average IOM content. Removal of the IOM prior to the chemical analysis by LA-ICP-MS or mathematical correction for the IOMderived magnesium concentrations is therefore strongly advised. The different chemistry of the IOM may also exert a major control on the trace element to calcium ratios. Shell portions enriched in IOM will show up to 200 times higher Mg/ $\mathrm{Ca}$ and up to two times higher $\mathrm{Sr} / \mathrm{Ca}$ ratios than the average shell of $A$. islandica. Without removal of the IOM prior to the analysis, $\mathrm{Mg} / \mathrm{Ca}$ and $\mathrm{Sr} / \mathrm{Ca}$ ratios of shell portions with higher IOM content cannot be used as paleothermometers. Because it is currently impossible to remove the IOM prior to chemical analyses by LA-ICP-MS, we recommend the use of wet chemical techniques (= possibility to separate and measure individual shell components) such as ICP-OES at the expense of lower sampling resolution. The results of this study will significantly improve our understanding of shellbased climate and environmental proxies.
\end{abstract}

Keywords: trace elements, bivalve shell, organics, LA-ICP-MS, ICP-OES, sclerochronology

\section{INTRODUCTION}

$\mathrm{Sr} / \mathrm{Ca}$ and $\mathrm{Mg} / \mathrm{Ca}$ ratios of biogenic carbonates can provide quantifiable data on ambient water temperature during biomineralization. This has been empirically dem-

\footnotetext{
*Corresponding author (e-mail: schoeneb@uni-mainz.de)

Copyright () 2010 by The Geochemical Society of Japan.
}

onstrated for a variety of different organisms including echinoids (Pilkey and Hower, 1960), brachiopods (Lowenstam, 1961), bivalves (Dodd, 1965, 1967), corals (Smith, 1979; Beck et al., 1992; Mitsuguchi et al., 1996), foraminifera (Nürnberg et al., 1996) and ostracods (Corrége, 1993). These studies were also complemented by inorganic precipitation experiments (Kinsman and Holland, 1969; Mucci, 1987). As temperature increases, the $\mathrm{Sr} / \mathrm{Ca}$ and $\mathrm{Mg} / \mathrm{Ca}$ ratios of abiogenic aragonites de- 
crease (Kinsman and Holland, 1969; Gaetani and Cohen, 2006), while those of abiogenic calcites increase (Katz, 1973; Mucci, 1987). In addition, strontium in calcite is strongly controlled by precipitation rate (Kinsman and Holland, 1969). The orthorhombic crystal structure of aragonite best accommodates the larger $\mathrm{Sr}^{2+}$ ion, while the rhombohedral crystal structure of calcite best accommodates the smaller $\mathrm{Mg}^{2+}$ ion. Therefore, aragonite often contains about 100 times more strontium than does calcite. Nonetheless, $\mathrm{Sr} / \mathrm{Ca}$ and $\mathrm{Mg} / \mathrm{Ca}$ ratios in either polymorph of calcium carbonate can provide serviceable paleothermometers.

However, the $\mathrm{Sr} / \mathrm{Ca}$ and $\mathrm{Mg} / \mathrm{Ca}$ ratios of biological carbonates often depart from apparent thermodynamic equilibrium. $\mathrm{Mg} / \mathrm{Ca}$ ratios of some calcitic (Dodd, 1965; Lorens and Bender, 1977; Freitas et al., 2005; Lorrain et al., 2005; Lazareth et al., 2007) and aragonitic bivalve shells (Takesue and van Geen, 2004) are lower than predicted by thermodynamics. Shell $\mathrm{Mg} / \mathrm{Ca}$ and $\mathrm{Sr} / \mathrm{Ca}$ ratios can also vary contradictorily among different species and even among conspecific and contemporaneous specimens from one locality (corals: Cardinal et al., 2001; brachiopods: England et al., 2007; bivalves: Dodd, 1965; Gillikin et al., 2005a; Lorrain et al., 2005; Freitas et al., 2008). Dodd (1965) also reported an inverse relation between temperature and $\mathrm{Sr} / \mathrm{Ca}$ ratios in the nacreous (aragonitic) shell layer of Mytilus edulis, while Gillikin et al. (2005a) observed the opposite in the aragonitic shell of Saxidomus gigantea. The ratios of trace elements to calcium show little consistency in the long-lived bivalve mollusk, Arctica islandica (Toland et al., 2000). Skeletal $\mathrm{Mg}$ and $\mathrm{Sr}$ contents sometimes correlate with skeletal growth (corals: de Villiers et al., 1995; bivalves: Swan, 1956; Takesue and van Geen, 2004; Gillikin et al., 2005a Lorrain et al., 2005), and also with ontogenetic age (Palacios et al., 1994; Freitas et al., 2005). Such findings suggest that non-thermodynamic factors (e.g., an active, protein-mediated removal of $\mathrm{Mg}$ from the inorganic carbonate phase during biomineralization) influence the incorporation of trace elements into biogenic carbonates.

It has also been suggested that organics may influence the skeletal metal content, but such relations have not been quantified (Allison, 1996; Nürnberg et al., 1996; Watanabe et al., 2001; Dauphin et al., 2003; Takesue and van Geen, 2004; Foster et al., 2008). Organics occur both within (intracrystalline; Pokroy et al., 2006; Jacob et al., 2008) and between (intercrystalline) $\mathrm{CaCO}_{3}$ crystals. During shell formation, these organic components mediate biomineralization (Lowenstam, 1981; Veis, 2003). The main biopolymers of bivalve mollusks are water-insoluble structural proteins ( $\beta$-chitin), water-soluble polyanionic proteins and silk-like proteins (LeviKalisman et al., 2001; Sudo et al., 1997). Some of these proteins can be enriched in certain trace elements, fore- most magnesium (Cowan, 1991). Nürnberg et al. (1996) estimated that up to $5 \%$ of $\mathrm{Mg}$ in bulk foraminiferan tests may be associated with proteins rather than with calcite. Likewise, Watanabe et al. (2001) showed that up to $40 \%$ of the magnesium in coral aragonite is not lattice-bound. Trace elements released from organic components during sample preparation or measurement may then increase estimates of $\mathrm{Mg}$ concentrations and $\mathrm{Mg} / \mathrm{Ca}$ ratios of biominerals. The metal contents of bivalve organs and tissues have been examined (e.g., Bustamante and Miramaud, 2004), but no study has yet quantified the $\mathrm{Mg}$ and $\mathrm{Sr}$ content of isolated shell organic matrices and $\mathrm{CaCO}_{3}$ phases.

Analytical techniques such as laser ablation-inductively coupled plasma-mass spectrometry (LA-ICP-MS) and ion microprobe are now widely used to study the skeletal composition in situ. LA-ICP-MS especially offers undeniable advantages with respect to spatial sampling resolution and sample throughput. But combining results for $\mathrm{CaCO}_{3}$ crystals and organic matrices potentially complicates interpretations (Watanabe et al., 2001). Only a few studies have compared results from LA-ICP-MS with wet chemical techniques that separate the organic and inorganic phases (Rosenheim et al., 2005; Gillikin et al., 2005a).

This paper quantifies the organic matrix and $\mathrm{CaCO}_{3}$ fractions in shells of $A$. islandica and presents the $\mathrm{Mg}, \mathrm{Sr}$ and $\mathrm{Ca}$ concentrations and $\mathrm{Mg} / \mathrm{Ca}$ and $\mathrm{Sr} / \mathrm{Ca}$ ratios for both phases, using wet chemical techniques combined with inductively coupled plasma-optical emission spectrometry (ICP-OES). It compares these results with LA-ICP-MS analyses. The benefits of special pretreatment methods and mathematical data corrections are then addressed. The results improve our understanding of trace element chemistry of biogenic skeletons, and can pave the road toward better climate and environmental proxies.

\section{Material AND Methods}

Eight specimens of Arctica islandica were used in the present study (Table 1). The bivalves were collected alive by dredging from $c a$. 25 to $55 \mathrm{~m}$ of water depth northwest of Iceland and from the North Sea (Table 1). Soft tissues were removed, and ligament and periostracum were physically abraded. The outer $c a$. $1000 \mu \mathrm{m}$ of each valve were also mechanically removed to eliminate adhering sediment and shell materials possibly altered by early diagenesis. The valves were then ultrasonically rinsed with de-ionized water.

Sample preparation for chemical analyses of different shell components

Five specimens were chosen (ICE06-A1 to A5; Table 
1) for the analysis of $\mathrm{Mg}, \mathrm{Sr}$ and $\mathrm{Ca}$ contents of the different shell components, i.e., the insoluble organic matrix $(\mathrm{IOM})$, the soluble organics $(\mathrm{SOM}=$ sugars, proteins etc.) and the inorganic calcium carbonate component $\left(\mathrm{CaCO}_{3}\right)$. The shells were ultrasonically rinsed multiple times in millipore (18.2 M $\Omega$ ) water, dried and weighed. Both valves of specimens ICE06-A1 and ICE06-A2 and one valve of each of the remaining specimens (whole, uncrushed valves) were gently dissolved in 5\% ultrapure $\mathrm{HNO}_{3}$ over several days before centrifuging the solution at 3700 RPM for $30 \mathrm{~min}$. We used a diluted acid to ensure that water-insoluble organics (IOM) were not dissolved and could be analyzed separately. Then, the IOM of each solution was extracted and rinsed multiple times in millipore water, air-dried and weighed. The IOM of one valve of specimens ICE06-A1 and ICE06-A2 were mounted on glass slides and their chemical composition determined by means of LA-ICP-MS (Table 1). The other IOM samples were completely digested in a 1:1 mixture of $30 \mathrm{vol} \%$ ultrapure $\mathrm{H}_{2} \mathrm{O}_{2}$ plus $65 \mathrm{vol} \%$ ultrapure $\mathrm{HNO}_{3}$ at $90^{\circ} \mathrm{C}$ (Bellotto and Miekeley, 2007).

After extraction of the IOM, the remaining fluid consisted of SOM and dissolved $\mathrm{CaCO}_{3}$. For two specimens (Table 1), the SOM with molecular sizes larger than $3 \mathrm{kDa}$ $\left(\mathrm{SOM}_{1 \mathrm{p}}\right)$ was separated from $\mathrm{SOM}$ with proteins smaller than $3 \mathrm{kDa}\left(\mathrm{SOM}_{\mathrm{sp}}\right)$ plus dissolved $\mathrm{CaCO}_{3}$ by ultrafiltration. To achieve this, the fluids were centrifuged at 3,700 RPM for more than 90 min in Vivispin filters (Sartorius, $20 \mathrm{ml}$ ). Additionally, the solutions containing $\mathrm{SOM}_{\mathrm{lp}}$ were also rinsed in millipore water. In order to prevent precipitation of trace elements, we added $1 \mathrm{ml} 65 \%$ ultrapure $\mathrm{HNO}_{3}$ to each of the dissolved shell components (IOM, $\mathrm{SOM}+\mathrm{CaCO}_{3}, \mathrm{SOM}_{\mathrm{lp}}, \mathrm{SOM}_{\mathrm{sp}}+\mathrm{CaCO}_{3}$ ). All wet fractions were weighed and then analyzed in a Spectro Ciros Vision ICP-OES at the University of Mainz.

Preparation of shell cross-sections for analyses of crystal fabric and chemistry

One valve of each of the remaining three specimens was mounted on a plexiglass cube and a quick-drying epoxy resin applied to the outer and inner valve surface along the axis of maximum growth (Table 1). On that axis, one or two $c a$. three-millimeter-thick sections were cut from each valve with a Buehler low-speed saw. The crosssectioned slabs were mounted on glass slides, ground on glass plates with 800 and 1200 grit powder and finally polished on a Buehler G-cloth with $1 \mu \mathrm{m} \mathrm{Al}_{2} \mathrm{O}_{3}$ powder. Prior to the analyses, all samples were ultrasonically rinsed in millipore water.

Chemical analyses of shell cross-sections (LA-ICP-MS and ICP-OES)

One polished cross-section of each of the three specimens HM-Fla86-A1, WH241-597-A1R and DBG13.2-A1

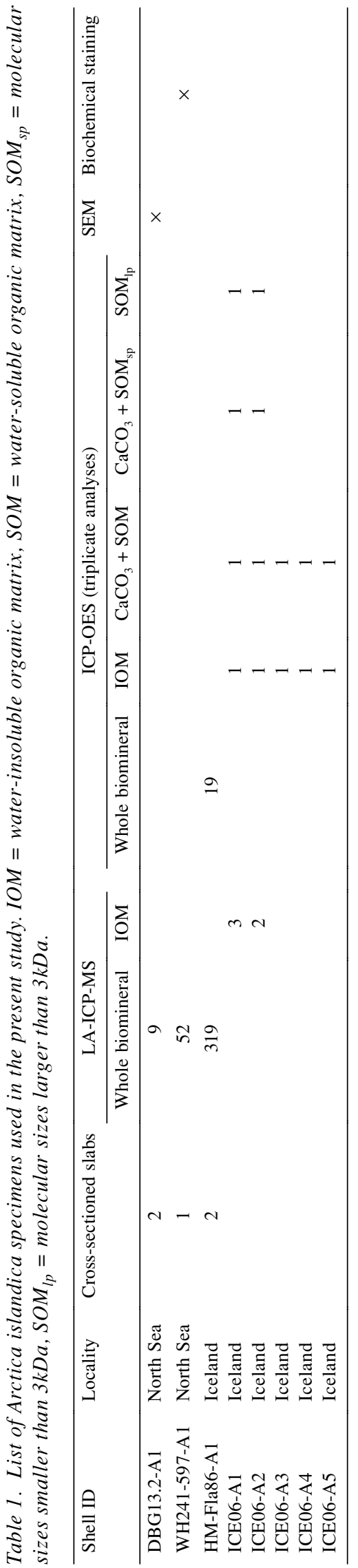

Chemistry of organic matrices of A. islandica 


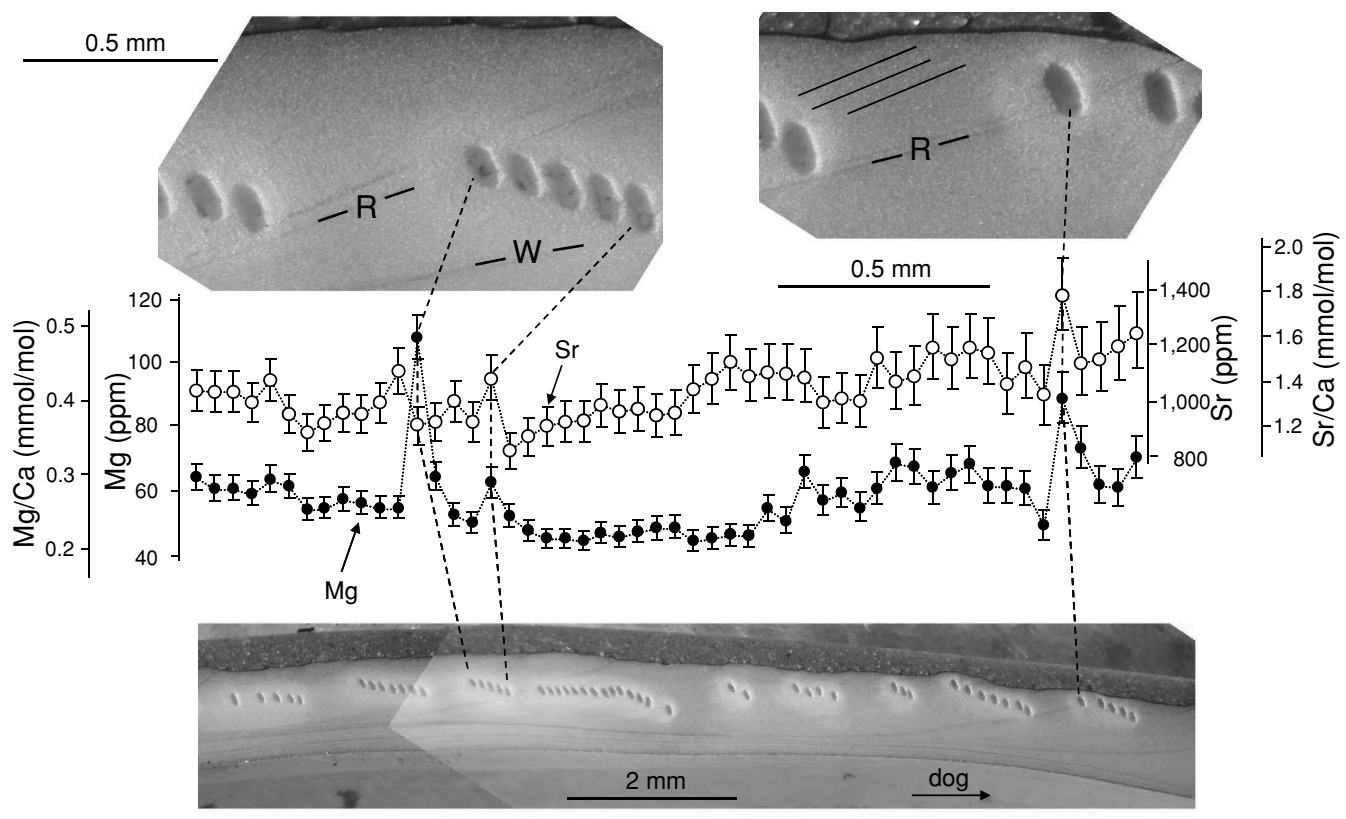

Fig. 1. Seasonal strontium and magnesium concentration and $\mathrm{Mg} / \mathrm{Ca}$ and $\mathrm{Sr} / \mathrm{Ca}$ ratios in cross-sectioned shell slab of Arctica islandica (specimen WH241-597-A1; Table 1). Data were obtained by LA-ICP-MS. Spots measured $100 \mu \mathrm{m}$ (long axis) in the direction of growth. Strongly enriched Mg content was observed at reproduction (" $R$ ") lines that formed during warm summer temperatures. These $\mathrm{Mg}$ peaks stood out significantly from values measured between consecutive reproduction lines. A slightly higher Mg value also occurred at the "W" line that formed during January/February. The Mg curve had a saw-toothed appearance, whilst the $S r$ values formed a relatively smooth curve with far less outstanding peaks at " $R$ " and " $W$ " lines. After sampling, the shells were immersed in Mutvei's solution that stained portions with a higher organic content deep blue (dark grey in black and white print) and those with less organics light blue (light grey). Note de-colored craters (white to light grey) around laser ablation spots. dog $=$ direction of growth. Error bars in standard deviation units $(1 \sigma)$.

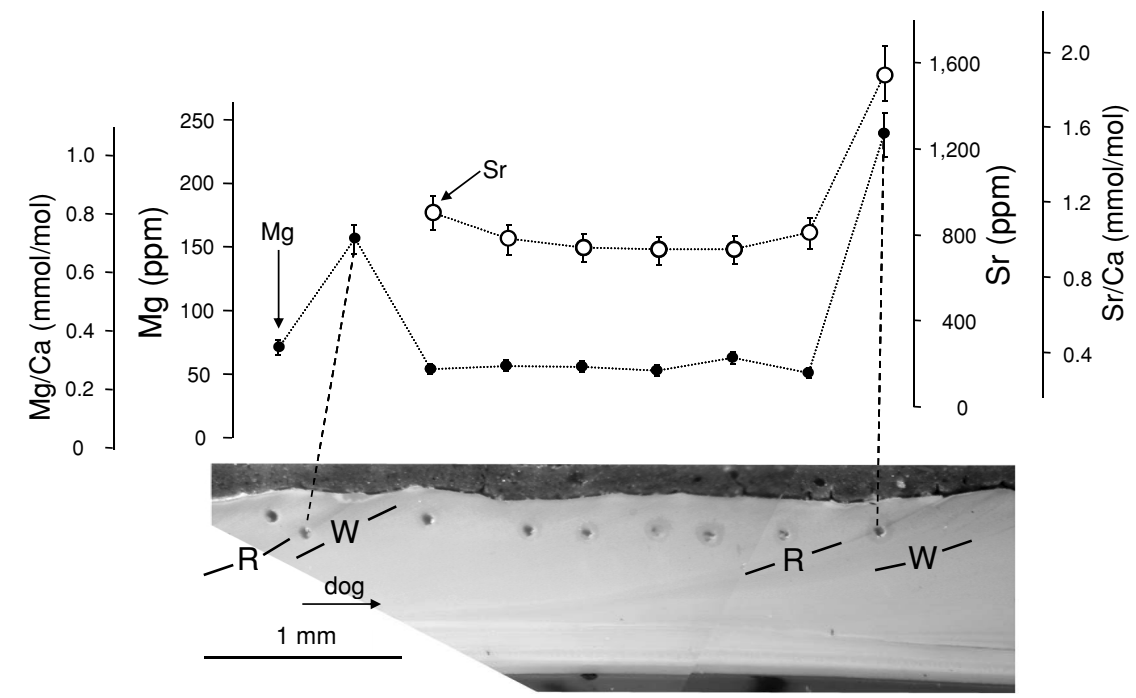

Fig. 2. Seasonal strontium and magnesium concentration and $M g / C a$ and Sr/Ca ratios in cross-sectioned shell slab of Arctica islandica (specimen DBG1.2-A1; Table 1). See description in caption of Fig. 1. dog = direction of growth. Error bars in standard deviation units $(1 \sigma)$. LA spot size is $50 \mu \mathrm{m}$ in diameter. 


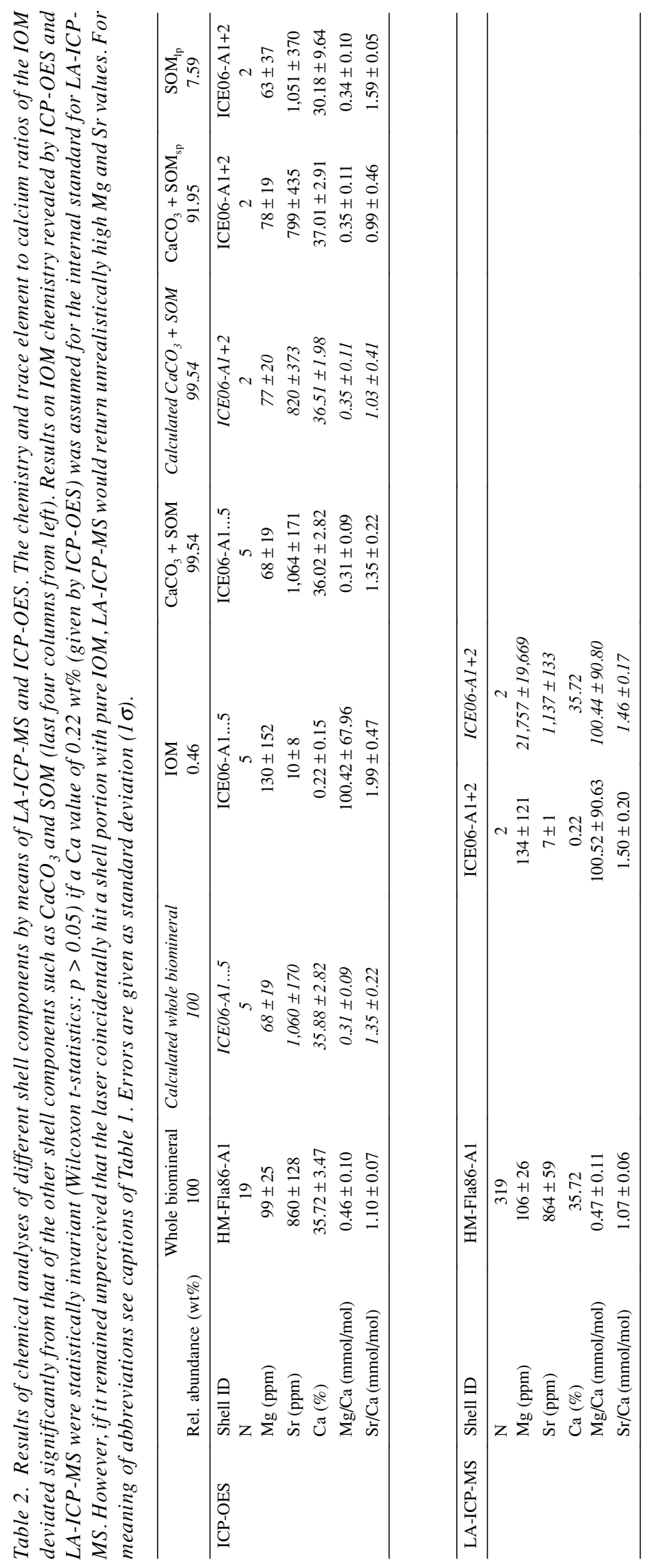


was analyzed by LA-ICP-MS (Table 1). Laser ablation spots in the outer shell layer measured $50 \mu \mathrm{m}$ in diameter in specimens HM-Fla86-A1 and DBG13.2-A1, and 100 $\mu \mathrm{m}$ in WH241-597-A1R. Specimens DBG13.2-A1 and WH241-597-A1R were used to study the intra-annual (seasonal) variations of trace elements. Therefore, only the youth portions of these shells were sampled, i.e., the shell portions that formed when the bivalves grew at the fastest rates. Each laser spot represented a shell portion that formed within days or a few weeks. In order to analyze the average trace element content, however, a shell portion near the ventral margin of specimen HMFla86-A1 was analyzed. The centers of individual laser spots were only approx. $3.45 \mu \mathrm{m}$ apart from each other and formed a line of measurements (Fig. 4). The lifespan of this bivalve exceeded 200 years, and the average annual increment width at the ventral margin was narrower than the diameter of a laser spot. Thus, each LA-ICP-MS sample from this specimen represented at least one year.

From the other polished slab of specimen HM-Fla86A1, aragonite powder was milled under a binocular microscope from the same shell portion that was analyzed by LA-ICP-MS (Table 1). We employed a cylindrical diamond drill bit (1 mm diameter, Komet/Gebr. Brasseler GmBH \& Co. KG model No. 835104 010) mounted on a Rexim Minimo drill. Spatial milling resolution parallel to the growth lines was about $55 \mu \mathrm{m}$. Each sample swath (55 $\mu \mathrm{m} \times 1.8 \mathrm{~mm})$ stretched from near the outer shell surface and toward the inside of the shell (approximately $2.8 \mathrm{~mm}$ away from the original outer shell surface; it should be noted that the LA-ICP-MS samples were located approx. 1.5 to $2 \mathrm{~mm}$ away from the original outer shell surface, i.e., ca. in the middle of the OES-sample swath; Fig. 4). Each of the shell powder samples weighed ca. 150 to $400 \mu \mathrm{g}$. Powder samples were completely dissolved in $1 \mathrm{ml} 70$ vol\% ultrapure $\mathrm{HNO}_{3}$ and visually confirmed to be without residue before dilution in $4 \mathrm{ml}$ millipore water. These samples were analyzed in a Spectro CIROS $^{\text {CCD }}$ SOP ICP-OES at the University of Kiel.

\section{Biochemical staining and analysis of the shell crystal fab- ric}

In order to identify the distribution of organic components of the shell and study the crystal fabric (Fig. 3), the remaining polished slab of specimen DBG13.1-A2 and the cross-section of WH241-597-A1R that was previously used for LA-ICP-MS were immersed in Mutvei's solution for 25 and $2 \mathrm{~min}$, respectively, at $37-40^{\circ} \mathrm{C}$ under constant stirring (Schöne et al., 2005a). Immediately afterward, the etched sections were rinsed in de-ionized water and allowed to air-dry. Mutvei's solution consists of $0.5 \mathrm{vol} \%$ acetic acid, $12.5 \mathrm{vol} \%$ glutardialdehyde and ca. 5 g Alcian Blue per liter solution. The acid gently etches the carbonate portions, while the glutardialdehyde preserves the organic matrix in three dimensions. Simultaneously, the Alcian Blue stains organic components deeply blue. Mutvei's solution is adequate for resolving shell internal growth structures. For scanning electron microscopy (SEM; Hitachi S 4300) the etched shell section of DBG13.1-A2 was sputter-coated with a $30 \AA$ gold layer.

\section{LA-ICP-MS analyses}

Solid shell material (Figs. 1, 2 and 4; Table 2) and IOM (Table 2) were analyzed for $\mathrm{Mg}$, by measurement of the isotope ${ }^{24} \mathrm{Mg}$, and $\mathrm{Sr}$ as ${ }^{88} \mathrm{Sr}$ by LA-ICP-MS at the University of Mainz. Ablation was achieved with a NewWave Research UP-213 Nd:YAG laser ablation system (New Wave Research), using a pulse rate of 4-10 $\mathrm{Hz}$, a pulse energy of $\sim 0.3 \mathrm{~mJ}$ per spot, and 50 and 100 $\mu \mathrm{m}$ spot diameters with $\mathrm{Ar}$ (or a He/Ar mixture) as ablation gas. Analyses were performed on an Agilent 7500ce ICP-MS coupled to the UP-213 platform (one point per peak and $10 \mathrm{~ms}$ dwell time) following methods described in Jacob (2006). SRM NIST SRM 612 was used as the external standard (Pearce et al., 1997), and the U.S. Geological Survey glass standard BCR-2G was measured to monitor accuracy and instrumental drift. ${ }^{43} \mathrm{Ca}$ was used as the internal standard with $\mathrm{Ca}$ concentrations measured by ICP-OES. Detection limits generally range between 0.001 and $0.5 \mathrm{ppm}$ for these elements. Relative standard deviations (based on repeated measurements of the external standard) were $7.2 \%$ for $\mathrm{Mg}$ and $7.8 \%$ for $\mathrm{Sr}$.

\section{ICP-OES analyses}

Dissolved shell samples of five specimens (ICE06A1 to A5; Table 2) were analyzed with a Spectro CIROS Vision ICP-OES system at the University of Mainz and sample HM-Fla86-A1 with a Spectro CIROS ${ }^{\text {CD }}$ SOP ICP-OES at the University of Kiel (Table 2). We followed the techniques described by Schrag (1999) and de Villiers et al. (2002). Relative standard deviations (triplicate measurements of each sample) were $0.99 \%$ for $\mathrm{Ca}, 1.39 \%$ for $\mathrm{Mg}$, and $1.34 \%$ for $\mathrm{Sr}$; accuracy for these elements was better than $0.5 \%$. Mixed standard solutions were prepared from single element standards of $\mathrm{Mg}, \mathrm{Sr}$ and $\mathrm{Ca}$ in proportions to reflect those observed in bivalve shells and organic components.

\section{Results}

According to our findings, shells of Arctica islandica consist, on average, of $99.54 \mathrm{wt} \%$ calcium carbonate $\left(\mathrm{CaCO}_{3}\right)$ and water-soluble organic matrix (SOM), and $0.46 \pm 0.19 \mathrm{wt} \%$ water-insoluble organic matrix (IOM) (Table 2). In what follows, $\mathrm{CaCO}_{3}+\mathrm{SOM}+\mathrm{IOM}$ are referred to as "whole biomineral". 


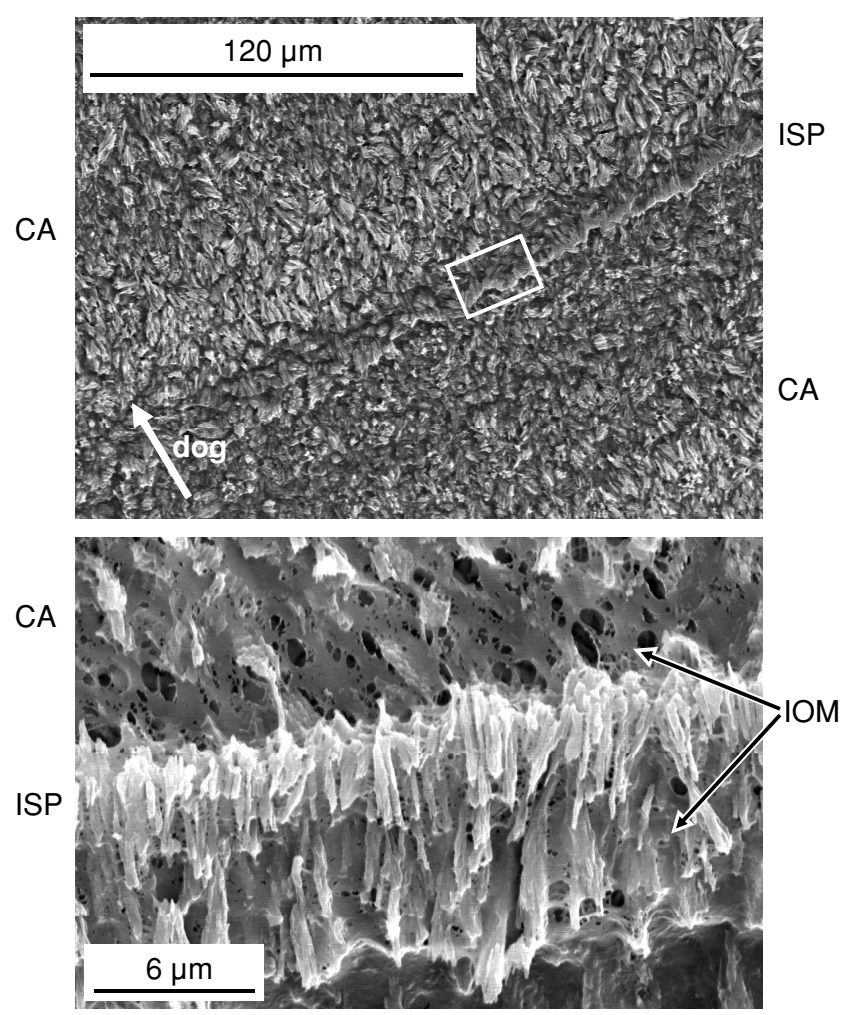

Fig. 3. SEM image of shell portion Arctica islandica (specimen DBG1.2-A1) near major annual growth line (reproduction line). Prior to coating with Au, sample was immersed in Mutvei's solution for two minutes. Cross-acicular crystal fabric (CA) prevails between major growth lines, whereas irregular simple prismatic crystal fabric (ISP) is observed at the growth line. Note that CA crystal sizes decrease prior to growth line. Because each crystal is surrounded by IOM, decreasing crystal sizes near growth lines result in relative enrichment of IOM and greater resistance of respective shell portions against etching. Therefore, these shell portions stand out as ridges. After the growth line, IOM is depleted, crystals are larger and the shell is more deeply etched. dog = direction of growth.

Distribution of organics across the shell of Arctica islandica

As shown by the sample immersed in Mutvei's solution (Fig. 1), growth lines were deeply stained by Alcian Blue while the portions between major growth lines were mottled in lighter blue colors. Notably, craters produced by laser ablation and the immediate adjacency of these spots were not stained (Fig. 1). SEM images of the etched outer shell layer of A. islandica revealed a cross-acicular crystal fabric between major growth lines (Fig. 3). Toward the annual growth lines, however, the size of these crystals gradually decreased and the amount of insoluble organics increased (Fig. 3). Even smaller, more etchresistant, tightly packed crystals (irregular simple prisms) were observed at the growth lines (Fig. 3).

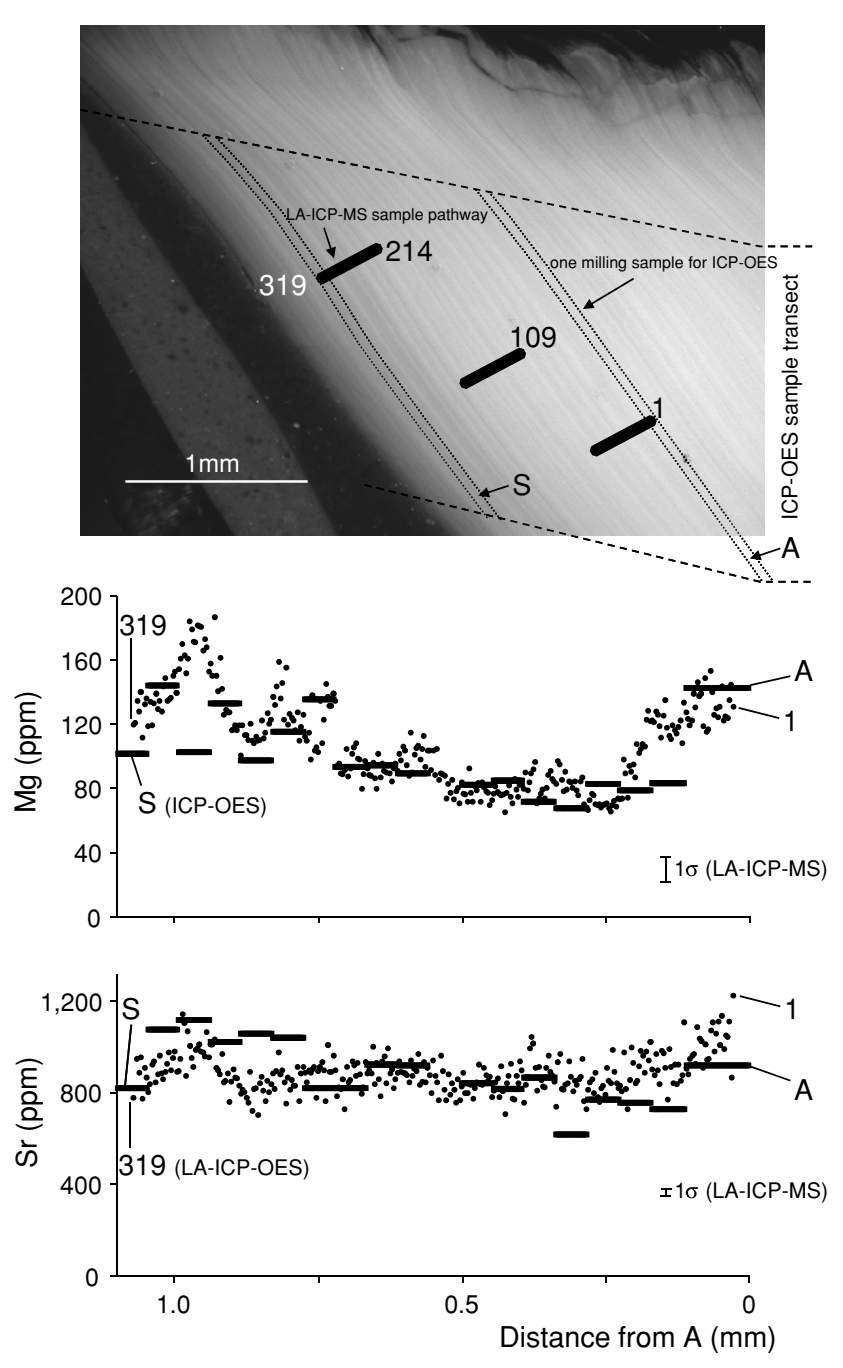

Fig. 4. Shell portion near the commissure of a more than 200 year-old specimen of Arctica islandica (specimen HM-Fla86A1; Table 2) sampled by ICP-OES (samples A to S) and LAICP-MS (samples 1 to 319). Distinct lines are annual growth lines. LA spot size is $50 \mu \mathrm{m}$ in diameter. Distance between LA spot centers was $3.45 \mu \mathrm{m} . \mathrm{Mg}$ and $\mathrm{Sr}$ concentrations measured by both analytical techniques were statistically indistinguishable (Wilcoxon t-statistsics: $p>0.05$ ). Error bars in standard deviation units $(1 \sigma)$. Error bars for ICP-OES results are smaller than size of labels.

Small-scale (LA-ICP-MS) element variation across the shell of Arctica islandica

Magnesium and strontium concentrations in the outer layer of $A$. islandica shells determined by LA-ICP-MS exhibited seasonal oscillations with sharp Mg excursions (Figs. 1 and 2). Highest magnesium values of 106 and $238 \mathrm{ppm}\left(\mu \mathrm{g} \mathrm{g}^{-1}\right)$ and strontium values of 1387 and 1466 ppm (Figs. 1 and 2) were observed near the major growth lines (" $R$ ") of two different specimens. These values corresponded to $\mathrm{Mg} / \mathrm{Ca}$ ratios of 0.49 and $1.10 \mathrm{mmol} / \mathrm{mol}$ 


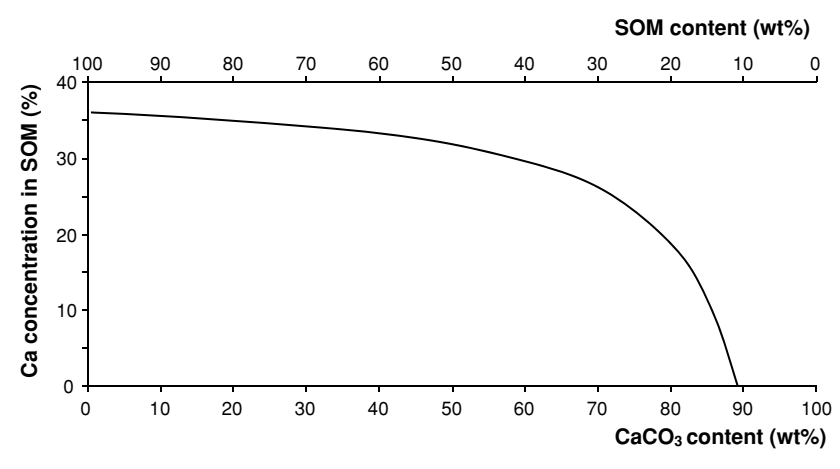

Fig. 5. Model to estimate the relative abundance of soluble organics in shells of Arctica islandica. The Ca content of the whole biomineral was determined by ICP-OES and equals 35.72 $w t \%$ (Table 2). This value limits the pure $\mathrm{CaCO}_{3}$ content to $89.21 \mathrm{wt} \%$. Accordingly, the minimum amount of soluble organics equals $10.33 \mathrm{wt} \%(100 \mathrm{wt} \%-0.46 \mathrm{wt} \%$ IOM-89.21 wt\% $\mathrm{CaCO}_{3}$ ). In this case, the SOM would contain no $\mathrm{Ca}$. With increasing amounts of $\mathrm{Ca}$ in the $\mathrm{SOM}$, the relative abundance of the SOM in the biomineral increases and the $\mathrm{CaCO}_{3}$ content decreases. The hypothetical extreme is where the "biomineral" is $\mathrm{CaCO}_{3}$-free and consists only of organics, i.e., $0.46 \mathrm{wt} \%$ IOM and $99.54 w t \%$ SOM.

and $\mathrm{Sr} / \mathrm{Ca}$ ratios of 1.78 and $1.88 \mathrm{mmol} / \mathrm{mol}$. Major growth lines (=reproduction lines; Jones, 1980) form about one month after the hottest part of summer (Fig. 1; Schöne et al., 2005b). A second magnesium peak occurred at growth lines denoted as "W" for winter (Fig. 1). These lines were laid down during $c a$. January/February (Schöne et al., $2005 \mathrm{~b}$ ). Lowest magnesium ( 45 and $55 \mathrm{ppm}=\mathrm{Mg} / \mathrm{Ca}$ of 0.21 and $0.26 \mathrm{mmol} / \mathrm{mol}$ ) and strontium (845 and $740 \mathrm{ppm}$ $=\mathrm{Sr} / \mathrm{Ca}$ of 1.08 and $0.95 \mathrm{mmol} / \mathrm{mol}$; Figs. 1 and 2) levels, however, occurred in shell portions that formed during the coldest season of the year, i.e., shortly after the "W" lines. Whereas strontium data formed relatively smooth curves, the magnesium curves demonstrated a saw-toothed appearance with two to three times higher values in samples that comprise major growth lines than samples from shell portions between two consecutive lines (Figs. 1 and 2).

Element analyses of Arctica islandica shell by LA-ICP$M S$ and ICP-OES

Contemporaneously deposited shell portions analyzed with different analytical techniques revealed statistically indistinguishable results for $\mathrm{Mg}$ and $\mathrm{Sr}$ as well as $\mathrm{Mg} / \mathrm{Ca}$ and $\mathrm{Sr} / \mathrm{Ca}$ ratios (Wilcoxon $t$-statistics: $p>0.05$ ) (Table 2; Fig. 4). According to ICP-OES analysis, the average Ca concentration in these shell portions was $35.72 \mathrm{wt} \%$. This value was used as the internal standard for LA-ICPMS.
Compound-specific chemical analyses by ICP-OES and $L A-I C P-M S$

Average ICP-OES-derived magnesium concentrations of the IOM (130 ppm; specimens ICE06-A1 to A5) can be up to two times as high as the whole biomineral or the soluble components (68 ppm; Table 2). However, strontium and calcium contents were much lower in the IOM compared to the biomineral ( $10 \mathrm{ppm}$ and $0.22 \mathrm{wt} \%$, respectively; Table 2). No statistical difference was found between $\mathrm{Mg}$ and $\mathrm{Sr}$ values or the $\mathrm{Mg} / \mathrm{Ca}$ and $\mathrm{Sr} / \mathrm{Ca}$ ratios of the IOM determined by ICP-OES and LA-ICP-MS if a $\mathrm{Ca}$ value of $0.22 \mathrm{wt} \%$ (= the Ca content in the IOM measured with ICP-OES) was used as the internal standard (Table 2).

Separation of soluble organics with large $\left(\mathrm{SOM}_{\mathrm{lp}}\right)$ and small proteins plus $\mathrm{CaCO}_{3}\left(\mathrm{CaCO}_{3}+\mathrm{SOM}_{\text {sp }}\right)$ was not successful (Table 2). As demonstrated by a Ca concentration of $30.18 \mathrm{wt} \%$, the $\mathrm{SOM}_{\mathrm{lp}}$ component still contained large amounts of dissolved $\mathrm{CaCO}_{3}$. Overall, water-soluble organics $\left(\mathrm{SOM}_{\mathrm{lp}}\right.$ and $\left.\mathrm{CaCO}_{3}+\mathrm{SOM}_{\mathrm{sp}}\right)$ were largely within the same range of magnesium and strontium concentrations as the whole biomineral (Table 2).

\section{Soluble organics: relative abundance and Ca concentra-} tion

The relative abundance of SOM in shells of $A$. islandica can be computed as follows. According to ICPOES, the whole biomineral contained $35.72 \mathrm{wt} \% \mathrm{Ca}$ (Table 2). This value represents the sum of the relative abundances of the three main components of the shell, $\mathrm{CaCO}_{3}$, IOM and SOM, and their respective Ca contents.

$$
35.72 \mathrm{wt} \%=\frac{a}{100} \cdot A+\frac{b}{100} \cdot B+\frac{c}{100} \cdot C,
$$

where $a, b$ and $c$ are the relative abundance in wt $\%$ of the $\mathrm{IOM}, \mathrm{CaCO}_{3}$ and SOM, respectively, and $a=0.46 \mathrm{wt} \%$, and $c=100 \mathrm{wt} \%-a-b . A, B$ and $C$ denote the Ca content (wt\%) of the IOM, $\mathrm{CaCO}_{3}$ and SOM, respectively, and $A=0.22 \mathrm{wt} \% \mathrm{Ca}$ (given by ICP-OES) and $B=40.04$ wt $\% \mathrm{Ca}$ (stoichiometrical value for abiogenic $\mathrm{CaCO}_{3}$ ). We can rewrite Eq. (1) as follows:

$$
\begin{aligned}
35.72 \mathrm{wt} \% \mathrm{Ca}= & \frac{0.46 \mathrm{wt} \%}{100} \cdot 0.22 \mathrm{wt} \% \mathrm{Ca} \\
& +\frac{b}{100} \cdot 40.04 \mathrm{wt} \% \mathrm{Ca} \\
& +\frac{100 \mathrm{wt} \%-0.46 \mathrm{wt} \%-b}{100} \cdot C
\end{aligned}
$$

and solve Eq. (2) for $C$ 


$$
\begin{aligned}
C= & \{35.72 \mathrm{wt} \% \mathrm{Ca}-0.0046 \mathrm{wt} \% \cdot 0.22 \mathrm{wt} \% \mathrm{Ca} \\
& \left.-\frac{b}{100} \cdot 40.04 \mathrm{wt} \% \mathrm{Ca}\right\} / \frac{100 \mathrm{wt} \%-0.46 \mathrm{wt} \%-b}{100} .
\end{aligned}
$$

According to the graphic representation of Eq. (3) (Fig. 5), the minimum SOM (c) and maximum possible $\mathrm{CaCO}_{3}$ content (b) of the whole biomineral is $10.33 \mathrm{wt} \%$ and $89.21 \mathrm{wt} \%$, respectively. At this value, the SOM contains no $\mathrm{Ca}(C=0 \mathrm{wt} \% \mathrm{Ca})$. With increasing $\mathrm{Ca}$ concentration in the SOM, the relative abundance of SOM in the biomineral increases and, correspondingly, the $\mathrm{CaCO}_{3}$ content of the mixture decreases. The maximum possible Ca level of the SOM $(C=35.88 \mathrm{wt} \% \mathrm{Ca})$ is attained when the entire hypothetical "biomineral" consists only of IOM and SOM $(c=99.54 \mathrm{wt} \%)$.

\section{Discussion}

\section{Chemical composition of the insoluble organic matrix}

The results of this study demonstrate that considerable amounts of magnesium in shells of Arctica islandica are organic-bound (IOM) rather than crystal-bound. In addition, the IOM has a different elemental composition than the inorganic carbonate phase plus soluble organics. On average, the insoluble organic matrix can contain nearly twice as much $\mathrm{Mg}$ as the whole biomineral or the soluble components $\left(\mathrm{CaCO}_{3}+\mathrm{SOM}\right)$, but $c a .99 \%$ less strontium and calcium (Table 2). Likewise, the $\mathrm{Mg} / \mathrm{Ca}$ ratios of the IOM can be up to 200 times higher than the whole biomineral, and the $\mathrm{Sr} / \mathrm{Ca}$ ratios two times higher (Table 2).

Similar findings have been reported for corals (e.g., Amiel et al., 1973; Sinclair et al., 1998; Fallon et al., 1999), foraminifera (Nürnberg et al., 1996), and most recently the bivalve mollusk Corbula amurensis (Takesue et al., 2008). For example, Allison (1996) observed significantly larger amounts of magnesium in organic-rich portions of coral skeletons and suggested that these metals are complexated by proteins (Mitterer, 1978). Watanabe et al. (2001) conducted several different pretreatment procedures to remove the organic components and adhering metals of coral skeletons. They concluded that $40 \%$ or the total skeletal magnesium is absorbed by organic components or crystal surfaces. The amount of non-lattice-bound magnesium in coral skeletons reported by Watanabe et al. (2001) compares well to our findings.

Comparable studies on bivalve shells are still scarce. However, Takesue and van Geen (2004) found lower Mg levels in subfossil Protothaca staminea shells than in modern samples of the same species and concluded that the $\mathrm{Mg}$-rich organic matrix had degraded during diagenesis (Curtis and Krinsley, 1965; Brand and Morrison, 1987). Similarly, Gillikin et al. (2005b) noted lower $\mathrm{Mg} / \mathrm{Ca}$ ratios in subfossil Mercenaria spp. analyzed with LA-ICP-MS. It is noteworthy, that none of the existing studies differentiated between insoluble and soluble organics.

Most recently, Foster et al. (2008) analyzed shells of Arctica islandica by means of Synchrotron X-ray Absorption Near Edge Spectroscopy (XANES) and concluded that $\mathrm{Mg}$ is not substituted into the aragonite of $A$. islandica, but is exclusively hosted by a disordered phase such as organic components or nanoparticles. According to these authors, $\mathrm{Mg}$ does not appear to be a useful paleoenvironmental proxy at all. However, Mg contents in shells of $A$. islandica approach those of current synchrotron methods. Most Mg levels of shells analyzed in the present study remained between 68 and $99 \mathrm{ppm}$. Therefore, the conclusions drawn by Foster et al. (2008) seem debatable and require further study.

The affinity of $\mathrm{Mg}$ for the IOM may result from the existence of organic molecules (metalloproteins, metal complexes etc.) with magnesium-binding capacities (Gómez-Ariza et al., 2004; Gotliv et al., 2005). Actually, $\mathrm{Mg}$ is one of the most abundant cofactors of metalloproteins (Dudev and Lim, 2000) and occurs at negatively charged sites of aspartic and glutamic-rich polypeptides (Dudev et al., 1999). These two amino acids belong to the most common constituents of glycoproteins of the molluscan extrapallial fluid (EPF) and play an active role in promoting and modulating shell mineral growth (Sikes et al., 1998; Gotliv et al., 2003). Later during biomineralization, these acidic macromolecules mainly become part of the intracrystalline matrix (Addadi et al., 1991) while other framework building insoluble components are mainly preserved as intercrystalline matrix. Furthermore, similar proteins sequestrate and remove metal ions from metabolic pathways. This is necessary because excessive amounts of such ions (mainly derived from food, Chapman et al., 2003) can have adverse effects on organisms. Different metal cation detoxification systems have therefore been developed in organisms (Viarengo and Nott, 1993). A common detoxification system is based upon soluble ligands, i.e., metal-binding proteins such as metallothioneins or phosphoproteins (Margoshes and Vallee, 1957; Noel-Lambot, 1976; Marsh and Sass, 1985). These proteins may become part of the EPF.

Some proportions of $\mathrm{Mg}$ may merely co-occur with the IOM. During biomineralization, $\mathrm{Mg}$ is largely excluded from aragonite crystals and is therefore enriched in the peripheral fluids surrounding the crystals. In this case, Mg does not necessarily bind to the IOM, but may be adhesively associated with the IOM (or occur as a $\mathrm{Mg}$ enriched $\mathrm{Mg}-\mathrm{Ca}-\mathrm{CO}_{3}$ surface coating on the carbonate crystals). However, the use of a low-concentration acid $\left(\mathrm{HNO}_{3}\right)$ in the present study to dissolve the biominerals 
assured that adhesively bound $\mathrm{Mg}$ was removed from the IOM prior to the analyses.

\section{IOM and magnesium distribution across shells of Arctica islandica}

As demonstrated by geochemical staining experiments (immersion in Mutvei's solution, Fig. 1) and SEM analyses (Fig. 3), organic components, especially the IOM, are not homogeneously distributed across the shells, but are strongly enriched near major growth lines. Mutvei's solution stained these lines dark blue indicating the presence of large amounts of organic molecules. In addition, SEM analyses revealed that significantly smaller crystals occur near such growth lines compared to other portions of the outer shell layer. Because each crystal is embedded in an organic sheet of IOM, shell portions with smaller crystals contain relatively larger amounts of intercrystalline organics. During biomineralization, these organic matrices provide the structural framework (Clark, 1980) and control the material properties of the biominerals (Mann, 1983; Simkiss and Wilbur, 1989; Crenshaw, 1990; Watabe et al., 1993). Between major growth lines, however, a cross-acicular crystal fabric with larger crystal sizes prevailed, and the amount of insoluble organics in the respective shell portions was much smaller. Immersion of such shell portions in Mutvei's solution resulted in a mottled fabric consisting of large, light blue (probably intracrystalline organics) stained crystals and scanty intercrystalline organics (darker blue).

\section{Pitfalls of element analyses of Arctica islandica shells by} $L A-I C P-M S$

If the precise $\mathrm{Ca}$ concentration of the analyzed material is known, LA-ICP-MS returns trace element values that are statistically indistinguishable from those measured by ICP-OES. For example, using the observed $\mathrm{Ca}$ concentration of $0.22 \mathrm{wt} \%$ (Table 2) as an internal standard, LA-ICP-MS and ICP-OES returned similar Mg and Sr data for the IOM (Table 2). This finding also suggests that potential interferences by organics on mass 24 have only minor effects on the $\mathrm{Mg}$ measurements. If organic molecules would influence the data, LA-ICP-MS values for the $\mathrm{Mg}$ concentration would be significantly different from those measured by ICP-OES. Likewise, a direct comparison of similar shell portions analyzed by LA-ICP-MS and ICP-OES revealed statistically indistinguishable trace element concentrations (Table 2). It should be noted that the analyzed samples came from an ontogenetically old shell portion. Low calcification rates in such shell portions resulted in narrow annual increments. Each sample taken from such locations represented more than a year of shell growth precluding the analysis of seasonal variations of trace elements. Given the relatively low sampling resolution, the distribution of the IOM (and the Ca level; here: $35.72 \mathrm{wt} \%$ ) in such shell portions can be considered to be nearly homogeneous.

However, fast-growing youth portions of bivalve shells can be analyzed with sub-annual resolution by LA-ICPMS. In such shell portions, the $\mathrm{Mg}$ concentration (and $\mathrm{Mg} / \mathrm{Ca}$ ratios) near major growth lines (=larger amounts of IOM) were two- to threefold higher than in neighboring shell portions with lower IOM content (Figs. 1 and 2). A likely explanation for the overestimation of the $\mathrm{Mg}$ concentration of shell portions enriched in IOM is a significant $\mathrm{Mg}$ contribution from the larger amounts of IOM present. In most existing LA-ICP-MS studies of biogenic hard parts, the small-scale heterogeneous distribution of the IOM across the shell and its chemical composition has received little attention. Instead of determining the precise $\mathrm{Ca}$ concentration of each shell portion designated for element analyses by means of LA-ICP-MS, it is often standard practice to measure the Ca concentration of the entire shell and use this value as the internal standard. However, the IOM to $\mathrm{CaCO}_{3}$ ratio across the shell is highly variable, particularly in youth portions of the shell, and shell portions containing more IOM evidently contain less $\mathrm{CaCO}_{3}$ and, thus, have a lower $\mathrm{Ca}$ content. It should be noted that it is currently very difficult to determine the $\mathrm{Ca}$ concentration of the sample volume ablated for LA-ICP-MS, because the sample volume excited by the electron microprobe for $\mathrm{Ca}$ measurements is much smaller. In spots, in which the amount of IOM exceeds $0.46 \mathrm{wt} \%$ of the total sample weight, this can result in a significant overestimation of the $\mathrm{Mg}$ and $\mathrm{Sr}$ concentration, whereas lower than average amounts can result in an underestimation of these elements. This will be demonstrated by a hypothetical model (Fig. 6).

In this model, we use a Ca content of $35.72 \mathrm{wt} \%$ as internal standard value (Ca concentration given by multiple ICP-OES measurements; Table 2) for all calculations. In the two extreme cases, (a) ablation of an IOMfree shell portion and (b) coincidental ablation of a purely organic spot, the $\mathrm{Mg}$ and $\mathrm{Sr}$ concentrations will be underestimated (a) or overestimated (b), respectively. In case (b), an unchanged internal standard value that does not take into account the admixture of virtually $\mathrm{Ca}$-free, but Mg- and Sr-rich IOM would result in an overestimation of the actual $\mathrm{Mg}$ and $\mathrm{Sr}$ concentrations $(\mathrm{Mg}=134 \mathrm{ppm}$; $\mathrm{Sr}=7 \mathrm{ppm})$ by $16,139 \%$ and $16,400 \%$, respectively $(\mathrm{Mg}$ $=21,761 \mathrm{ppm} ; \mathrm{Sr}=1,155 \mathrm{ppm}$; Table 2$)$. A mixing model for these two end members, $0 \mathrm{wt} \%$ and $100 \mathrm{wt} \%$ IOM, provides a means to estimate the potential error induced by different amounts of IOM in the biomineral (Fig. 6). For example, if a shell portion containing $50 \mathrm{wt} \%$ insoluble organics is ablated, apparent $\mathrm{Mg}$ and $\mathrm{Sr}$ values would be as high as 237 and 866 ppm, respectively. These hypothetical considerations demonstrate that a local enrichment of IOM can lead to a significant overestimation of 


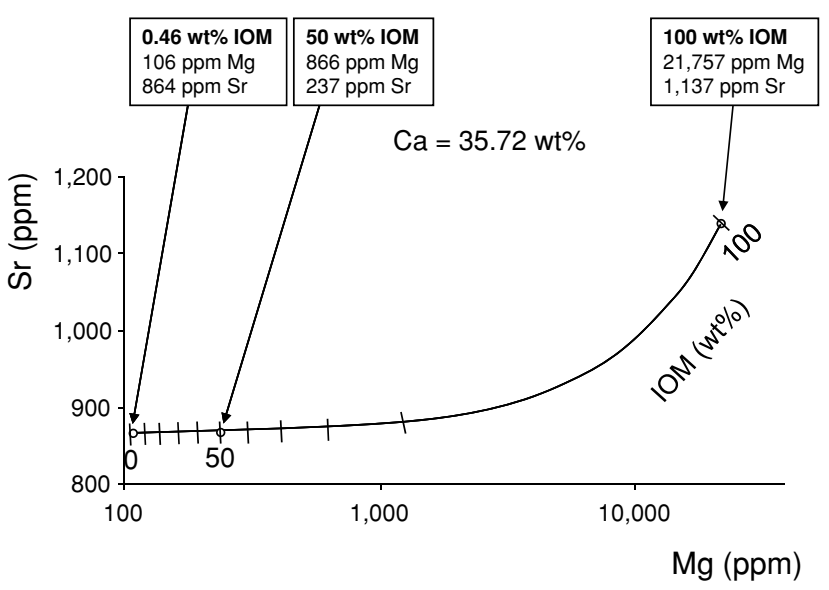

Fig. 6. Hypothetical model of the potential error of trace element chemistry induced by spatially variable amounts of IOM. Here, it is assumed that the Ca concentration of the sample spot analyzed by means of LA-ICP-MS is not known precisely and an internal standard value of $35.72 \mathrm{wt} \% \mathrm{Ca}$ (given by ICPOES analysis) is erroneously assumed. If the laser hit a shell portion without IOM, all $\mathrm{Mg}$ and $\mathrm{Sr}$ would come from the $\mathrm{CaCO}_{3}$ + SOM fraction. However, assuming that the laser coincidently hit a shell portion containing pure IOM, this would result in a significant overestimation of the $\mathrm{Mg}$ and $\mathrm{Sr}$ concentrations of 21,761 ppm and 1,155 ppm, respectively. A mixing model for these two end members, $0 \mathrm{wt} \%$ and $100 \mathrm{wt} \%$ IOM, provides a means to estimating the potential error induced by different amounts of IOM in the biomineral.

the $\mathrm{Mg}$ level of the sampled shell portion if the actual $\mathrm{Ca}$ concentration is not precisely determined. Precisely how the IOM concentration varies across the shell on $\mu \mathrm{m}$ - and nm-scales remains to be studied.

Trace element to calcium ratios of Arctica islandica shells

So far, our analyses have demonstrated that element concentrations of homogeneous shell portions and isolated IOM measured by ICP-OES and LA-ICP-MS agree well. Furthermore, the $\mathrm{Mg} / \mathrm{Ca}$ and $\mathrm{Sr} / \mathrm{Ca}$ ratios calculated from the respective ICP-OES and LA-ICP-MS data were statistically identical (Table 2). However, as shown in Figs. 1 and 2, high-resolution LA-ICP-MS analysis of fastgrowing youth portions of the shells not only resulted in higher Mg values near major, IOM-enriched growth lines, but also in elevated $\mathrm{Mg} / \mathrm{Ca}$ ratios. This is likely to be due to the different chemical composition of the IOM and the $\mathrm{CaCO}_{3}+\mathrm{SOM}$ components. In the model in Fig. 7, the effect of increasing amounts of IOM on the $\mathrm{Mg} / \mathrm{Ca}$ and $\mathrm{Sr} / \mathrm{Ca}$ ratios is simulated. If the analyzed shell portions consist of pure IOM, $\mathrm{Mg} / \mathrm{Ca}$ and $\mathrm{Sr} / \mathrm{Ca}$ ratios are $c a$. 100.44 and $1.46 \mathrm{mmol} / \mathrm{mol}$, respectively. However, in an assumed extreme case that the analyzed shell portions consist of a 1:1 mixture (by weight) of IOM and $\mathrm{CaCO}_{3}$

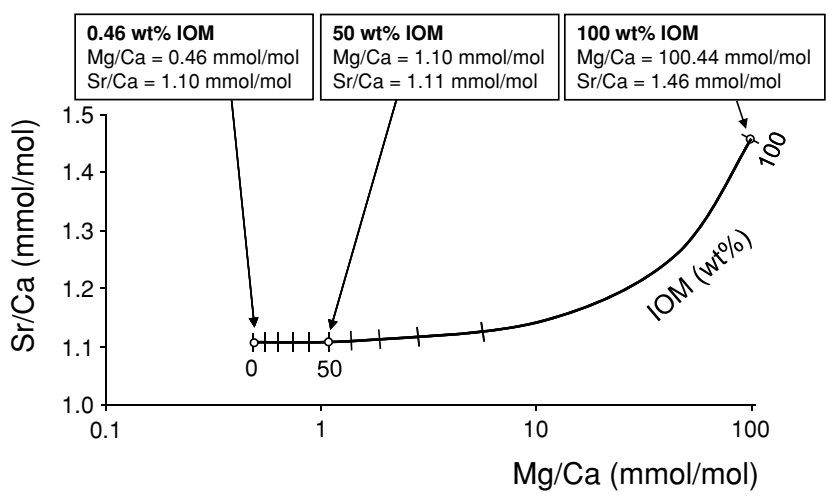

Fig. 7. Model of IOM-induced changes of the trace element to calcium ratios of a biomineral. Because of the different element chemistry of the IOM (Table 2), $\mathrm{Mg} / \mathrm{Ca}$ and $\mathrm{Sr} / \mathrm{Ca}$ ratios increase with increasing relative abundance of IOM in the biomineral.

$+\mathrm{SOM}$, the $\mathrm{Mg} / \mathrm{Ca}$ and $\mathrm{Sr} / \mathrm{Ca}$ ratios will amount to 1.10 and $1.11 \mathrm{mmol} / \mathrm{mol}$, respectively. For the calculation, we assumed that the $\mathrm{CaCO}_{3}$ to $\mathrm{SOM}$ ratio remained unchanged and that SOM was Ca-free. Therefore, the relative abundance of $\mathrm{CaCO}_{3}$ amounts to $44.81 \mathrm{wt} \%$, and the Ca concentration will be $44.81 \mathrm{wt} \% \times 40.04 \mathrm{wt} \% \mathrm{Ca} / 100$ $=17.94 \mathrm{wt} \%$ (for calculation of the SOM abundance and Ca content in SOM see next section). For comparison, the average shell $(0.46 \mathrm{wt} \% \mathrm{IOM})$ returned $\mathrm{Mg} / \mathrm{Ca}$ ratios of $0.46 \mathrm{~mol} / \mathrm{mol}$ and $\mathrm{Sr} / \mathrm{Ca}$ ratios of $1.10 \mathrm{mmol} / \mathrm{mol}$. This model suggests that shell portions enriched in IOM can have higher $\mathrm{Mg} / \mathrm{Ca}$ and-if the IOM content is large enough-higher $\mathrm{Sr} / \mathrm{Ca}$ ratios. Trace element to calcium ratios of shell portions enriched in IOM may not be useful as paleothermometers, because the relationship between temperature and $\mathrm{Mg} / \mathrm{Ca}$ and $\mathrm{Sr} / \mathrm{Ca}$ ratios has only been verified for $\mathrm{CaCO}_{3}$, but not for the IOM.

\section{Soluble organics (SOM)}

It is currently very difficult to ascertain the trace elemental composition of the soluble organics or the precise relative abundance of $\mathrm{SOM}_{\mathrm{lp}}$ and $\mathrm{SOM}_{\mathrm{sp}}$ in the whole biomineral. Our approach to separate the soluble organics by molecular size was not successful, because the $\mathrm{SOM}_{\mathrm{lp}}$ fraction apparently still contained large amounts of dissolved $\mathrm{CaCO}_{3}$ (Table 2). Preliminary data, however, suggest that the chemical composition of the SOM does not vary as much as the IOM from the inorganic shell fraction. Other available techniques to separate the SOM from the $\mathrm{CaCO}_{3}$ involve cationic ion exchange resin (Albeck et al., 1996). However, these methods involve non-ultrapure agents and are thus inappropriate to determine the trace element composition of the SOM.

It is noteworthy that the relative abundance of SOM in the shells of $A$. islandica was unexpectedly high in 
comparison to previous reports. Kawaguchi and Watabe (1993) found only $2.6 \mathrm{wt} \%$ IOM + SOM in Crassostrea virginica shells. However, these data came from the prismatic shell layer which may contain considerably less organics than the crystal fabrics of $A$. islandica. Typically, the prismatic shell layer is only very weakly stained by Mutvei's solution indicating low amounts of organics (Schöne et al., 2005a). Further studies are required to confirm the amounts of SOM in A. islandica shells.

\section{Implications for geochemical analyses of bivalve shells}

As demonstrated here, an indiscriminate use of analytical techniques may produce imprecise data on trace element concentrations of bivalve shells. Strontium levels of bivalve shells can be determined with sufficient precision and accuracy by both ICP-OES and LA-ICPMS techniques. However, $\mathrm{Mg}$ concentrations are severely overestimated by LA-ICP-MS, because (1) the IOM is enriched in $\mathrm{Mg}$ and (2) the internal standard value assumed for the whole biomineral may not be appropriate to each shell portion; some shell portions such those as near major growth lines can be significantly enriched in IOM and, thus, depleted in Ca compared to the whole biomineral. Without proper sample pretreatment or mathematical modeling, high-resolution LA-ICP-MS-derived $\mathrm{Mg}$ concentrations cannot be compared with ICP-OES data. Potential sample pretreatment procedures can include removal of the IOM by oxidative cleaning (see Takesue and van Geen, 2004). However, some of the intracrystalline organic matrix may be insoluble as well and thus difficult to remove (e.g., by roasting; Gaffey et al., 1991), without dissolving the shell (compare Watanabe et al., 2001). Alternatively, the surplus of $\mathrm{Mg}$ contained in the IOM can be mathematically corrected for. If the average IOM content and its artifactual $\mathrm{Mg}$ concentration were known, its contribution to the $\mathrm{Mg}$ concentrations of the whole biomineral could be calculated and subtracted.

The use of trace element to calcium ratios as faithful paleothermometers, however, does not require absolute element concentrations. Even if the exact Ca-concentration of the ablated material is not known due to the heterogeneous nature of the material, $\mathrm{Mg}$ and $\mathrm{Sr}$ values will change proportionally, and $\mathrm{Mg} / \mathrm{Ca}$ or $\mathrm{Sr} / \mathrm{Ca}$ ratios will not be fractionated. However, existing studies (inorganic precipitation experiments) have only confirmed a temperature effect on the $\mathrm{Mg} / \mathrm{Ca}$ and $\mathrm{Sr} / \mathrm{Ca}$ ratios of the $\mathrm{CaCO}_{3}$, while such effects on the IOM have never been studied. Given the different chemical composition of the IOM, shell portions enriched in IOM will not only show higher $\mathrm{Mg}, \mathrm{Sr}$ and $\mathrm{Ca}$ concentrations, but also higher $\mathrm{Mg} / \mathrm{Ca}$ and $\mathrm{Sr} / \mathrm{Ca}$ ratios than the $\mathrm{CaCO}_{3}+\mathrm{SOM}$ fraction. This is applicable to both the ICP-OES and LA-ICP-MS techniques. However, wet analytical techniques permit the separation of the different shell components prior to the analysis, whereas a reliable removal of the IOM from the biomineral prior to LA-ICP-MS analysis is not currently established. During LA-ICP-MS analysis the entire shell material is ablated, i.e., IOM, SOM and $\mathrm{CaCO}_{3}$. Therefore, shell portions with higher relative IOM abundance will return elevated $\mathrm{Mg} / \mathrm{Ca}$ and $\mathrm{Sr} / \mathrm{Ca}$ ratios. Without removal of the IOM prior to the analysis, $\mathrm{Mg} / \mathrm{Ca}$ and $\mathrm{Sr} / \mathrm{Ca}$ ratios of shell portions with higher IOM content cannot be used as paleothermometers.

\section{SUMMARY AND CONCLUSIONS}

The insoluble organic matrix of Arctica islandica shells is significantly enriched in magnesium and depleted in strontium and calcium in comparison with the inorganic carbonate fraction and soluble organics. Although the average relative abundance of the IOM barely exceeds $0.5 \%$ by weight, its chemical composition can significantly increase estimates of the $\mathrm{Mg}$ content of the shell if measured by LA-ICP-MS. This overestimation is related to the heterogeneous distribution (on $\mu \mathrm{m}$ - and nm-scales) of the IOM across the shells. It is currently still very difficult to determine the $\mathrm{Ca}$ concentration (used as internal standard) of the exact same volume that is ablated for LA-ICP-MS. Thus, Mg concentrations of shell portions with higher than average IOM content, such as major growth lines, are prone to be overestimated by LA-ICPMS. Removal of the IOM prior to the chemical analysis or mathematical correction for the IOM-derived magnesium concentrations is strongly advised.

For paleoenvironmental reconstructions, however, it is necessary to determine the element to calcium ratios of the $\mathrm{CaCO}_{3}$ component. Existing studies (inorganic precipitation experiments) have only demonstrated a temperature effect on the $\mathrm{Mg} / \mathrm{Ca}$ and $\mathrm{Sr} / \mathrm{Ca}$ ratios of the $\mathrm{CaCO}_{3}$, but not of the IOM. Without removal of the IOM prior to the analysis, $\mathrm{Mg} / \mathrm{Ca}$ and $\mathrm{Sr} / \mathrm{Ca}$ ratios of shell portions enriched in IOM cannot be used as paleothermometers. Because it is currently not possible to remove the IOM prior to LA-ICP-MS analysis, we recommend the use of wet chemical techniques such as ICPOES at the expense of lower sampling resolution.

The trace metal chemistry of soluble organics in biominerals still requires further study. Our preliminary approach only focused on molecular sizes of the SOM above and below $3 \mathrm{kDa}$ and separation of these two phases from dissolved $\mathrm{CaCO}_{3}$ was incomplete. Chromatographic separation methods (Mazon et al., 1990) may help to determine the $\mathrm{Mg}$ content in different molecule size classes as well as the relative abundance of each different SOM class in the whole biomineral. Such data may help to define mathematical models that can eliminate the potential overestimation of Mg by means of LA-ICP-MS. 
Similar influences of organic proteins on chemical estimates are also expected for other metals that are often bound to organic molecules such as $\mathrm{Co}, \mathrm{Fe}, \mathrm{Mn}, \mathrm{Mo}$, $\mathrm{Ni}$, Se and Zn (e.g., Lochmüller et al., 1974; Gómez-Ariza et al., 2004). Further studies should therefore isolate different organic components of the shell and determine their amount and chemical composition by wet chemical analyses.

Acknowledgments-Arctica islandica specimens DBG13.2-A1 and WH241-597-A1 were provided by Ingrid Kröncke (Marine Research Division, Senckenberg Institute, Wilhelmshaven, Germany), and specimen HM-Fla86-A1 by Harry Mutvei (Museum of Natural History, Stockholm, Sweden). Comments made by Elizabeth Nunn (University of Mainz) are kindly acknowledged. Two anonymous reviewers significantly helped to improve a former version of this manuscript; we are very grateful for their help. We also thank Tsuyoshi Watanabe for handling and communicating this manuscript. This study has been made possible by a German Research Foundation (DFG) grant (to Schöne: SCHO 793/4). A PhD scholarship to Zhang by the German Academic Exchange Service (DAAD) is kindly acknowledged. This is Geocycles publication number 619.

\section{REFERENCES}

Addadi, L., Berman, A. and Weiner, S. (1991) Intracrystalline proteins from a sea urchin and a mollusk: A comparison. Mechanisms and Phylogeny of Mineralization in Biological Systems (Suga, S. and Nakahara, H., eds.), 29-33, Springer.

Albeck, S., Weiner, S. and Addadi, L. (1996) Polysaccharides of intercrystalline glycoproteins modulate calcite growth in vitro. Chem. Eur. J. 2, 278-284.

Allison, N. (1996) Geochemical anomalies in coral skeletons and their possible implications for palaeoenvironmental analyses. Mar. Chem. 55, 367-379.

Amiel, A. J., Miller, D. S. and Friedman, G. M. (1973) Incorporation of uranium in modern corals. Sedimentology 20, 523-528.

Beck, J. W., Edwards, R. L., Ito, E., Taylor, F. W., Recy, J., Rougerie, F., Joannot, P. and Henin, C. (1992) Sea-surface temperature from coral skeletal strontium/calcium ratios. Science 257, 644-647.

Bellotto, V. R. and Miekeley, N. (2007) Trace metals in mussel shells and corresponding soft tissue samples: a validation experiment for the use of Perna perna shells in pollution monitoring. Anal. Bioanal. Chem. 389, 769-776.

Brand, U. and Morrison, J. O. (1987) Biogeochemistry of fossil marine invertebrates. Geosci. Can. 14, 85-107.

Bustamante, P. and Miramaud, P. (2004) Interspecific and geographical variations of trace element concentrations in Pectinidae from European waters. Chemosphere 57, 13551362.

Cardinal, D., Hamelin, B., Bard, E. and Pätzold, J. (2001) Sr/ $\mathrm{Ca}, \mathrm{U} / \mathrm{Ca}$ and $\delta^{18} \mathrm{O}$ records in recent massive corals from Bermuda: Relationships with sea surface temperature. Chem. Geol. 176, 213-233.
Chapman, P. M., Wang, F., Janssen, C. R., Goulet, R. R. and Kamunde, C. N. (2003) Conducting ecological risk assessments of inorganic metals and metalloids: current status. Human Ecol. Risk Assessm. 9, 641-697.

Clark, G. R., II. (1980) Techniques for observing the organic matrix of molluscan shells. Skeletal Growth of Aquatic Organisms (Rhoads, D. C. and Lutz, R. A., eds.), 607-612, Plenum Publ. Co.

Corrége, T. (1993) Preliminary results of paleotemperature reconstruction using the magnesium to calcium ratio of deepsea ostracod shells from the Late Quaternary of Site 822, Leg 133 (western Coral Sea). Proc. Ocean Drilling Prog. Sci Res. 133, 175-180.

Cowan, J. A. (1991) Metallobiochemistry of magnesium. Coordination complexes with biological substrates: site specificity, kinetics and thermodynamics of binding, and implications for activity. Inorg. Chem. 30, 2740-2747.

Crenshaw, M. A. (1990) Biomineralization mechanisms. Skeletal Biomineralization: Patterns, Processes and Evolutionary Trends, Volume 1 (Carter, J. G., ed.), 1-9, Van Nostrand Reinhold.

Curtis, C. D. and Krinsley, D. (1965) The detection of minor diagenetic alteration in shell material. Geochim. Cosmochim. Acta 29, 71-84.

Dauphin, Y., Cuif, J. P., Doucet, J., Salomé, M., Susini, J. and Williams, C. T. (2003) In situ mapping of growth lines in the calcitic prismatic layers of mollusc shells using X-ray absorption near-edge structure (XANES) spectroscopy at the sulphur K-edge. Mar. Biol. 142, 299-304.

de Villiers, S., Nelson, B. K. and Chivas, A. R. (1995) Biological controls on coral $\mathrm{Sr} / \mathrm{Ca}$ and $\delta^{18} \mathrm{O}$ reconstructions of seasurface temperatures. Science 269, 1247-1249.

de Villiers, S., Greaves, M. and Elderfield, H. (2002) An intensity ratio calibration method for the accurate determination of $\mathrm{Mg} / \mathrm{Ca}$ and $\mathrm{Sr} / \mathrm{Ca}$ of marine carbonates by ICP-AES. Geochem., Geophys., Geosyst. 3, 1001, doi:10.1029/ $2001 \mathrm{GC} 000169$.

Dodd, J. R. (1965) Environmental control of strontium and magnesium in Mytilus. Geochim. Cosmochim. Acta 29, 385398.

Dodd, J. R. (1967) Magnesium and strontium in calcareous skeletons: a review. J. Paleontol. 41, 1313-1329.

Dudev, T. and Lim, C. (2000) Metal binding in proteins: The importance of dielectric medium effects. J. Phys. Chem. B 104, 3692-3694.

Dudev, T., Cowan, J. and Lim, C. (1999) Competitive binding in magnesium coordination chemistry: water versus ligands of biological interest. J. Am. Chem. Soc. 121, 7665-7673.

England, J., Cusack, M. and Lee, M. R. (2007) Magnesium and sulphur in the calcite shells of two brachiopods, Terebratulina retusa and Novocrania anomala. Lethaia 40, 2-10.

Fallon, S. J., McCulloch, M. T., van Woesik, R. and Sinclair, D. J. (1999) Corals at their latitudinal limits: laser ablation trace element systematics in Porites from Shirigai Bay, Japan. Earth Planet. Sci. Lett. 172, 221-238.

Foster, L. C., Finch, A. A., Allison, N., Andersson, C. and Clarke, L. J. (2008) Mg in aragonitic bivalve shells: Seasonal variations and mode of incorporation in Arctica 
islandica. Chem. Geol. 254, 113-119.

Freitas, P., Clarke, L. J., Kennedy, H., Richardson, C. and Abrantes, F. (2005) Mg/Ca, Sr/Ca, and stable-isotope $\left(\delta^{18} \mathrm{O}\right.$ and $\delta^{13} \mathrm{C}$ ) ratio profiles from the fan mussel Pinna nobilis: Seasonal records and temperature relationships. Geochem., Geophys., Geosyst. 6, doi:10.1029/2004GC000872.

Freitas, P. S., Clarke, L. J., Kennedy, H. A. and Richardson, C. A. (2008) Inter- and intra-specimen variability masks reliable temperature control on shell $\mathrm{Mg} / \mathrm{Ca}$ ratios in laboratory- and field-cultured Mytilus edulis and Pecten maximus (bivalvia). Biogeosciences 5, 1245-1258.

Gaetani, G. A. and Cohen, A. L. (2006) Element partitioning during precipitation of aragonite from seawater: A framework for understanding paleoproxies. Geochim. Cosmochim. Acta 70, 4617-4634.

Gaffey, S. J., Kolak, J. J. and Bronnimann, C. E. (1991) Effects of drying, heating, annealing, and roasting of carbonate skeletal material, with geochemical and diagenetic implications. Geochim. Cosmochim. Acta 55, 1627-1640.

Gillikin, D. P., Lorrain, A., Navez, J., Taylor, J. W., André, L., Keppens, E., Baeyens, W. and Dehairs, F. (2005a) Strong biological controls on $\mathrm{Sr} / \mathrm{Ca}$ ratios in aragonitic marine bivalve shells. Geochem., Geophys., Geosyst. 6, doi:10.1029/ $2004 G C 000874$.

Gillikin, D. P., Dehairs, F., Baeyens, W., Navez, J., Lorrain, A. and André, J. (2005b) Inter- and intra-annual variations of $\mathrm{Pb} / \mathrm{Ca}$ ratios in clam shells (Mercenaria mercenaria): a record of anthropogenic lead pollution? Mar. Pollut. Bull. 50, 1530-1540.

Gómez-Ariza, J. L., García-Barrera, T., Lorenzo, F., Bernal, V., Villegas, M. J. and Oliveira, V. (2004) Use of mass spectrometry techniques for the characterization of metal bound to proteins (metallomics) in biological systems. Anal. Chim. Acta 524, 15-22.

Gotliv, B.-A., Addadi, L. and Weiner, S. (2003) Mollusk shell acidic proteins: in search of individual functions. Chembiochem 4, 522-529.

Gotliv, B.-A., Kessler, N., Sumerel, J. L., Morse, D. E., Tuross, N., Addadi, L. and Weiner, S. (2005) Asprich: a novel aspartic acid-rich protein family from the prismatic shell matrix of the bivalve Atrina rigida. Chembiochem 6, 304314.

Jacob, D. E. (2006) High sensitivity analysis of trace element poor geological reference glasses by laser-ablation inductively coupled plasma mass spectrometry (LA-ICP-MS). Geostand. Geoanalyt. Res. 30, 221-235.

Jacob, D. E., Soldati, A. L., Wirth, R., Huth, J., Wehrmeister, U. and Hofmeister, W. (2008) Nanostructure, chemical composition and mechanisms of bivalve shell growth. Geochim. Cosmochim. Acta, 72, 5401-5415.

Jones, D. S. (1980) Annual cycle of shell growth increment formation in two continental shelf bivalves and its paleoecological significance. Paleobiol. 6, 331-340.

Katz, A. (1973) The interaction of magnesium with calcite during crystal growth at $25-90^{\circ} \mathrm{C}$ and one atmosphere. Geochim. Cosmochim. Acta 37, 1563-1586.

Kawaguchi, T. and Watabe, N. (1993) The organic matrices of the shell of the American oyster Crassostrea virginica Gmelin. J. Exp. Mar. Biol. Ecol. 170, 11-28.
Kinsman, D. J. J. and Holland, H. D. (1969) The coprecipitation of cations with $\mathrm{CaCO}_{3}$. IV. The coprecipitation of $\mathrm{Sr}^{2+}$ with aragonite between $16^{\circ}$ and $96^{\circ} \mathrm{C}$. Geochim. Cosmochim. Acta 33, 1-17.

Lazareth, C. E., Guzman, N., Poitrasson, F., Candaudap, L. and Ortlieb, L. (2007) Nyctemeral variations of magnesium intake in the calcitic layer of a Chilean mollusk shell (Concholepas concholepas, Gastropoda). Geochim. Cosmochim. Acta 71, 5369-5383.

Levi-Kalisman, Y., Falini, G., Addadi, L. and Weiner, S. (2001) Structure of the nacreous organic matrix of a bivalve mollusk shell examined in the hydrated state using cryoTEM. J. Struct. Biol. 135, 8-17.

Lochmüller, C. H., Galbraith, J., Walter, R. L. and Willis, R. E. (1974) Metal-ion distribution in metalloproteins by protoninduced X-ray emission analysis. Analyt. Biochem. 57, 618622.

Lorens, R. B. and Bender, M. L. (1977) Physiological exclusion of magnesium from Mytilus edulis calcite. Nature $\mathbf{2 6 9}$, 793-794.

Lorrain, A., Gillikin, D. P., Paulet, Y.-M., Chauvaud, L., Le Mercier, A., Navez, J. and André, L. (2005) Strong kinetic effects on $\mathrm{Sr} / \mathrm{Ca}$ ratios in the calcitic bivalve Pecten maximus. Geology 33, 965-968.

Lowenstam, H. A. (1961) Mineralogy, $\mathrm{O}^{18} / \mathrm{O}^{16}$ ratios, and strontium and magnesium contents of Recent and fossil brachiopods and their bearing on the history of the oceans. J. Geol. 69, 241-260.

Lowenstam, H. A. (1981) Minerals formed by organisms. Science 211, 1126-1131.

Mann, S. (1983) Mineralization in biological systems. Struct. Bond. 54, 125-174.

Margoshes, M. and Vallee, B. L. (1957) A cadmium protein from equine kidney cortex. J. Am. Chem. Soc. 79, 48134814.

Marsh, M. E. and Sass, R. L. (1985) Distribution and characterization of mineral-binding phosphoprotein particles in bivalvia. J. Exp. Zool. 234, 237-242.

Mazon, A. Z., Storms, S. D. and Jenkins, K. D. (1990) Metalloprotein separation and analysis by directly coupled size exclusion high-performance liquid chromatography inductively coupled plasma mass spectroscopy. Analyt. Biochem. 186, 187-201.

Mitsuguchi, T., Matsumoto, E., Abe, O., Uchida, T. and Isdale, P. J. (1996) Mg/Ca thermometry in coral skeletons. Science 274, 961-962.

Mitterer, R. M. (1978) Amino acid composition and metal binding capability of the skeletal protein of corals. Bull. Mar. Sci. 28, 173-180.

Mucci, A. (1987) Influence of temperature on the composition of magnesian calcite overgrowths precipitated from seawater. Geochim. Cosmochim. Acta 51, 1977-1984.

Noel-Lambot, F. (1976) Distribution of cadmium, zinc and copper in the mussel Mytilus edulis. Existence of cadmiumbinding proteins similar to metallothioneins. Experientia 32, 324-326.

Nürnberg, D., Bijma, J. and Hemleben, C. (1996) Assessing the reliability of magnesium in foraminiferal calcite as a proxy for water mass temperatures. Geochim. Cosmochim. 
Acta 60, 803-814.

Palacios, R., Orensanz, J. M. and Armstrong, D. A. (1994) Seasonal and lifelong variation of $\mathrm{Sr} / \mathrm{Ca}$ ratio in shells of $M y a$ arenaria from Grays Harbor (Washington)_An ancillary criterion in demographic studies. Estuar., Coast. Shelf Sci. 39, 313-327.

Pearce, N. J. G., Perkins, W. T., Westgate, J. A., Gorton, M. P., Jackson, S. E., Neal, C. R. and Chenery, S. P. (1997) A compilation of new and published major and trace element data for NIST SRM 610 and NIST SRM 612 glass reference materials. Geostand. Newsl. 21, 115-144.

Pilkey, O. H. and Hower, J. (1960) The effect of environment on the concentration of skeletal magnesium and strontium in Dendraster. J. Geol. 68, 203-216.

Pokroy, B., Fitch, A. N., Lee, P. L., Quintana, J. P., Caspi, E. N. and Zolotoyabko, E. (2006) Anisotropic lattice distortions in the mollusk-made aragonite: a widespread phenomenon. J. Struct. Biol. 153, 145-150.

Rosenheim, B., Swart, P. K. and Thorrold, S. R. (2005) Minor and trace elements in sclerosponge Ceratoporella nicholsoni: Biogenic aragonite near the inorganic endmember? Palaeogeogr., Palaeoclimatol. Palaeoecol. 228, 109-129.

Schöne, B. R., Dunca, E., Fiebig, J. and Pfeiffer, M. (2005a). Mutvei's solution: an ideal agent for resolving microgrowth structures of biogenic carbonates. Palaeogeogr., Palaeoclimatol. Palaeoecol. 228, 149-166.

Schöne, B. R., Pfeiffer, M., Pohlmann, T. and Siegismund, F. (2005b) A seasonally resolved bottom water temperature record for the period of AD 1866-2002 based on shells of Arctica islandica (Mollusca, North Sea). Int. J. Climatol. 25, 947-962.

Schrag, D. P. (1999) Rapid analysis of high-precision $\mathrm{Sr} / \mathrm{Ca}$ ratios in corals and other marine carbonates. Paleoceanog. 14, 97-102.

Sikes, C. S., Wheeler, A. P., Wierzbicki, A., Dillman, R. M. and de Luca, L. (1998) Oyster shell protein and atomic force microscopy of oyster shell folia. Biol. Bull. 194, 304-316.

Simkiss, K. and Wilbur, K. M. (1989) Biomineralization. Cell
Biology and Mineral Deposition. Academic Press, San Diego, $337 \mathrm{pp}$.

Sinclair, D., Kinsley, L. P. J. and McCulloch, M. T. (1998) High resolution analysis of trace elements in corals by laser ablation ICP-MS. Geochim. Cosmochim. Acta 62, 1889-1901.

Smith, S. V. (1979) Strontium-calcium thermometry in coral skeletons. Science 204, 404-407.

Sudo, S., Fujikawa, T., Nagakura, T., Ohkubo, T., Sakaguchi, K., Tanaka, M., Nakashima, K. and Takahashi, T. (1997) Structures of mollusc shell framework proteins. Nature $\mathbf{3 8 7}$, 563-564.

Swan, E. F. (1956) The meaning of strontium-calcium ratios. Deep-Sea Res. 4, 71.

Takesue, R. K. and van Geen, A. (2004) $\mathrm{Mg} / \mathrm{Ca}, \mathrm{Sr} / \mathrm{Ca}$, and stable isotopes in modern and Holocene Protothaca staminea shells from a northern California coastal upwelling region. Geochim. Cosmochim. Acta 68, 3845-3861.

Takesue, R. K., Bacon, C. R. and Thompson, J. K. (2008) Influences of organic matter and calcification rate on trace elements in aragonitic estuarine bivalve shells. Geochim. Cosmochim. Acta 72, 5431-5445.

Toland, H., Perkins, B., Pearce, N., Keenan, F. and Leng, M. J. (2000) A study of sclerochronology by laser ablation ICPMS. J. Analyt. Atoms. Spectrom. 15, 1143-1148.

Veis, A. (2003) Mineralization in organic matrix frameworks. Rev. Mineral. Geochem. 54, 249-289.

Viarengo, A. and Nott, J. A. (1993) Mechanisms of heavy metal cation homeostasis in marine invertebrates. Comp. Biochem. Physiol. C 104, 355-372.

Watabe, N., Kingsley, R. J. and Kawaguchi, T. (1993) Functions of organic matrices in some invertebrate calcifying systems. Structure, Formation and Evolution of Fossil Hard Tissues (Kobayashi, I., Mutvei, H. and Sahni, A., eds.), 311, Tokai Univ. Press, Japan.

Watanabe, T., Minagawa, M., Oba, T. and Winter, A. (2001) Pretreatment of coral aragonite for $\mathrm{Mg}$ and $\mathrm{Sr}$ analysis: Implications for coral thermometers. Geochem. J. 35, 265269. 